\author{
Correspondence \\ Wen-Jun Li \\ wjli@ynu.edu.cn \\ Kannan Sivakumar \\ oceanactino@gmail.com
}

\section{Actinomadura sediminis sp. nov., a marine actinomycete isolated from mangrove sediment}

\author{
Jie He, ${ }^{1} \dagger$ Ying Xu, ${ }^{1}$ † Maloy Kumar Sahu, ${ }^{2}$ Xin-Peng Tian, ${ }^{3}$ Guo-Xing Nie, ${ }^{4}$ \\ Qiong Xie, ${ }^{5}$ Si Zhang, ${ }^{3}$ Kannan Sivakumar $^{2}$ and Wen-Jun Li,6
}
${ }^{1}$ Key Laboratory of Microbial Diversity in Southwest China, Ministry of Education and Laboratory for Conservation and Utilization of Bio-Resources, Yunnan Institute of Microbiology,
Yunnan University, Kunming 650091, PR China
${ }^{2}$ Centre of Advanced Study in Marine Biology, Faculty of Marine Science, Annamalai University, Parangipettai 608 502, Tamilnadu, India
${ }^{3}$ CAS Key Laboratory of Marine Bio-Resources Sustainable Utilization, RNAM Center for Marine Microbiology, CAS Guangdong Key Laboratory of Marine Materia Medica, South China Sea Institute of Oceanology, Chinese Academy of Sciences, Guangzhou 510301, PR China
${ }^{4}$ College of Life Science, Henan Normal University, Xinxiang 453007, PR China
${ }^{5}$ State Key Laboratory of Space Medicine Fundamentals and Application, China Astronaut Research and Training Center, Beijing 100094, PR China
${ }^{6}$ Key Laboratory of Biogeography and Bioresource in Arid Land, Xingjiang Institute of Ecology and Geography, Chinese Academy Of Sciences, Ürmqi 830011, PR China

\begin{abstract}
In this study, the taxonomic position of an actinobacterium, strain YIM M $10931^{\top}$, which was isolated from a mangrove sediment sample collected in Dugong Creek, Little Andaman, India, was determined by a polyphasic approach. This Gram-positive, aerobic strain produced branched substrate mycelium and aerial hyphae, which differentiated into short, hooked or spiral spore chains. The organism contained meso-diaminopimelic acid as the diagnostic diamino acid in the cell-wall peptidoglycan. The whole cell sugars consisted of mannose, ribose, glucose, galactose and madurose. The cellular fatty acid profile mainly consisted of iso- $\mathrm{C}_{16: 0}, 10$-methyl $\mathrm{C}_{18: 0}$ and $\mathrm{C}_{16: 0}$. The quinone system was predominantly composed of MK-9 $\left(\mathrm{H}_{8}\right)(45.5 \%)$ and MK-9 $\left(\mathrm{H}_{6}\right)$ (39\%). The phospholipids detected were diphosphatidylglycerol, phosphatidylglycerol, phosphatidylinositol mannoside, phosphatidylinositol and two unknown phospholipids. The organism showed a combination of morphological and chemotaxonomic properties typical of members of the genus Actinomadura. Moreover, phylogenetic analysis based on a $16 \mathrm{~S}$ rRNA gene sequence generated from the strain identified its closest relatives as Actinomadura cremea DSM $43676^{\top}$ (98.4\% sequence similarity), Actinomadura rifamycini DSM $43936^{\top}(97.4 \%)$ and Actinomadura apis IM1 $7-1^{\top}(96.9 \%)$. It was obvious from the resulting phylogenetic trees that strain YIM M $10931^{\top}$ belongs to a distinct subclade within the evolutionary radiation of the genus Actinomadura. DNA-DNA hybridizations of strain YIM M $10931^{\top}$ with $A$. cremea DSM $43676^{\top}$ and $A$. rifamycini DSM $43936^{\top}$ were performed and further confirmed that the isolate represents a separate genomic species. Based on the phenotypic and genotypic characteristics presented, it is proposed that strain YIM M $10931^{\top}$ represents a novel species within the genus Actinomadura, for which the name Actinomadura sediminis sp. nov. is proposed; the type strain is YIM M $10931^{\top}$

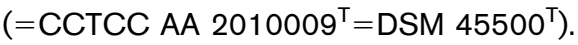

†These authors contributed equally to this work

Abbreviations: DAP, diaminopimelic acid; DPG, diphosphatidylglycerol; $\mathrm{Pl}$, phosphatidylinositol.

The GenBank/EMBL/DDBJ accession number for the 16S rRNA gene sequence of strain YIM M $10931^{\top}$ is JF272484.

Two supplementary figures and a supplementary table are available with the online version of this paper.
The mangrove, a typical ecosystem in tropical coastal biomes, is located at the transition area between the land and the sea (Holguin et al., 2001; Kathiresan \& Bingham, 2001), which plays a very important role as refuge, feeding, and breeding areas for many organisms and sustains an extensive food web based on detritus. It is distinguished from other ecosystems due to periodic tidal flooding and 
variable environmental factors, such as salinity and nutrient availability (Alongi, 1988; Holguin et al., 2006). Mangroves make up approximately $60-75 \%$ of all biotic communities in the world's tropical and subtropical coastlines (Holguin et al., 2001). In these ecosystems, the microbial community diversity has been poorly researched, compared with the well-documented species diversity of larger animals and plants (Xu et al., 2009).

The genus Actinomadura was established by Lechevalier \& Lechevalier (1968) and was placed in the family Thermomonosporaceae, which, at the time of writing, contained four other genera, Actinocorallia, Spirillospora, Thermomonospora and Actinoallomurus (Zhang et al., 1998; Trujillo \& Goodfellow, 2003; Tamura et al., 2009). At present, the genus Actinomadura comprises 44 recognized species, including the newly proposed species, Actinomadura apis and Actinomadura rifamycini (Promnuan et al., 2011), and Actinomadura scrupuli (Lee \& Lee, 2010). The emended genus Actinomadura represents aerobic, Gram-positive, non-acid-fast, non-motile actinomycetes that generate abundantly branched, non-fragmenting substrate mycelia and aerial hyphae that differentiate into various spore chain morphologies. These spore chains are short to long, straight, hooked or spiral (1-4 turns). Members of the genus Actinomadura are characterized by: the presence of mesodiaminopimelic acid (DAP) and madurose in the cell wall; MK- $9\left(\mathrm{H}_{4}\right)$, MK- $9\left(\mathrm{H}_{6}\right)$ and MK-9 $\left(\mathrm{H}_{8}\right)$ as the predominant menaquinones; hexadecanoic, 14-methylpentadecanoic and 10-methyloctadecanoic acids as the main fatty acids; and diphosphatidylglycerol (DPG) and phosphatidylinositol (PI) as major phospholipids (Kroppenstedt et al., 1990).

Strain YIM M $10931^{\mathrm{T}}$ was isolated from a mangrove sediment sample collected from Dugong Creek, Little Andaman, India $\left(10^{\circ} 48^{\prime} 43.1^{\prime \prime} \mathrm{N} 92^{\circ} 34^{\prime} 59.9^{\prime \prime} \mathrm{E}\right)$. Sediment ( $\left.1 \mathrm{~g}\right)$ was added to $9 \mathrm{ml}$ sterile distilled water and mixed by vortexing. A 10fold dilution of this soil suspension was prepared in sterilized distilled water and $0.1 \mathrm{ml}$ was spread on Kuster's agar medium (glycerol, $10 \mathrm{~g}$; casein, $0.3 \mathrm{~g} ; \mathrm{KNO}_{3}, 2 \mathrm{~g} ; \mathrm{NaCl}, 20 \mathrm{~g}$; $\mathrm{K}_{2} \mathrm{HPO}_{4}, 2 \mathrm{~g} ; \mathrm{MgSO}_{4} \cdot 7 \mathrm{H}_{2} \mathrm{O}, 0.05 \mathrm{~g} ; \mathrm{CaCO}_{3}, 0.02 \mathrm{~g} ; \mathrm{FeSO}_{4}$. $7 \mathrm{H}_{2} \mathrm{O}, 0.01 \mathrm{~g}$; agar, $15 \mathrm{~g} ; \mathrm{pH} 7.0 \pm 0.1$; distilled water, $1000 \mathrm{ml}$ ) and incubated at $28{ }^{\circ} \mathrm{C}$ for 21 days. The strain was cultivated and maintained on modified 2216 agar medium containing $\left(1^{-1}\right)$ : peptone, $1 \mathrm{~g}$; yeast extract, $1 \mathrm{~g}$; $\mathrm{FeSO}_{4} \cdot 7 \mathrm{H}_{2} \mathrm{O}, 0.001 \mathrm{~g} ;\left(\mathrm{NH}_{4}\right)_{2} \mathrm{SO}_{4}, 4 \mathrm{~g} ; \mathrm{CaCO}_{3}, 0.1 \mathrm{~g}$; agar, $20 \mathrm{~g}$ ( $\mathrm{pH}$ 7.2). Actinomadura cremea DSM $43676^{\mathrm{T}}$ and $A$. rifamycini DSM $43936^{\mathrm{T}}$ were used as reference strains and cultivated under the same conditions.

Strain YIM M $10931^{\mathrm{T}}$ and other type strains were cultured for $7,10,14$ and 21 days at $28{ }^{\circ} \mathrm{C}$ on modified 2216 agar medium and marine agar medium $\left[\mathrm{NaCl}, 19.45 \mathrm{~g} ; \mathrm{MgCl}_{2} .6 \mathrm{H}_{2} \mathrm{O}\right.$, $5.9 \mathrm{~g} ; \mathrm{Na}_{2} \mathrm{SO}_{4}, 3.24 \mathrm{~g} ; \mathrm{CaCl}_{2}, 1.9 \mathrm{~g}$; peptone, $5 \mathrm{~g}$; yeast extract, $1 \mathrm{~g} ; 2 \mathrm{ml}$ solution A containing $\left(1^{-1}\right.$ distilled water): ferric citrate, $5 \mathrm{~g}$; $\mathrm{KCl}, 4 \mathrm{~g}$; SeF, $1.7 \mathrm{~g} ; \mathrm{H}_{3} \mathrm{BO}_{3}, 1.1 \mathrm{~g}$ ); $1 \mathrm{ml}$ solution $\mathrm{B}$ containing $\left(\mathrm{l}^{-1}\right.$ distilled water): $\mathrm{Na}_{2} \mathrm{SiO}_{3}, 4 \mathrm{~g}$; NaF, $1.6 \mathrm{~g} ; \mathrm{NaNO}_{3}, 8 \mathrm{~g} ; \mathrm{Na}_{2} \mathrm{HPO}_{4}, 8 \mathrm{~g}$ ); and distilled water, $1000 \mathrm{ml}$ ] using the coverslip technique of Kawato \& Shinobu
(1959). Morphological properties were observed by using a light microscope (BH-2; Olympus) and a scanning electron microscope (Philips XL30; ESEM-TMP).

Cultural characteristics were determined on various agar media after 30 days at $28{ }^{\circ} \mathrm{C}$, according to the methods described by Shirling \& Gottlieb (1966). Colours of the aerial and substrate mycelia were determined by using colour chips from the ISCC-NBS colour charts (standard sample no. 2106; Kelly, 1964). Carbon-source utilization tests were performed according to the methods of Shirling \& Gottlieb (1966) and Athalye et al. (1985) using the basal medium recommended by Pridham \& Gottlieb (1948). Growth at various temperatures, $\mathrm{pH}$ values and $\mathrm{NaCl}$ concentrations was assessed using ISP 2 agar medium at $28{ }^{\circ} \mathrm{C}$ for 3 weeks. Degradation of cellulose, gelatin, urea, and Tweens 20, 40 and 80 was determined as described by Athalye et al. (1985). Antibiotic susceptibility was determined on ISP 2 agar medium incubated at $28{ }^{\circ} \mathrm{C}$ for 7 days by the disc diffusion plate method (Bauer et al., 1966); each antibiotic was tested at $10 \mu \mathrm{g}$ per disc. Catalase activity was tested using $10 \%(\mathrm{v} / \mathrm{v}) \mathrm{H}_{2} \mathrm{O}_{2}$ according the standard method. Other phenotypic characteristics were tested by using standard procedures (Goodfellow, 1971; Athalye et al., 1985).

Biomass for the study of chemotaxonomic characteristics was prepared by cultivation in tryptic soy broth (Difco) in shaken flasks at 170 r.p.m. at $28{ }^{\circ} \mathrm{C}$ for 7 days, harvested by centrifugation at 4500 r.p.m. (for $10 \mathrm{~min}$ ), washed twice with distilled water and then freeze-dried. The DAP isomer was identified by using TLC as described by Staneck \& Roberts (1974). The whole cell sugars were separated by HPLC after precolumn derivatization with 1-phenyl-3-methyl-5-pyrazolone (Tang et al., 2009). Phospholipids were determined according to published procedures (Minnikin et al., 1979; Collins \& Jones, 1980). Menaquinones were extracted (Collins et al., 1977) and detected by HPLC (Tamaoka et al., 1983). Cellular fatty acids were extracted, methylated and analysed by using the Sherlock Microbial Identification System (MIDI) according to the method of Sasser (1990) and the manufacturer's instructions. Fatty acid methyl esters were then analysed by GC (Agilent Technologies 7890A GC System) by using the Microbial Identification software package (Sherlock Version 6.1; MIDI database TSBA6).

Extraction of genomic DNA and PCR amplification of the $16 \mathrm{~S}$ rRNA gene were done as described by Li et al. (2007). Multiple alignments with sequences of the most closely related taxa and calculations of levels of sequence similarity were carried out using CLUSTAL_x (Thompson et al., 1997). Phylogenetic analyses were performed using three treemaking algorithms, namely, the neighbour-joining (Saitou \& Nei, 1987), maximum-likelihood (Felsenstein, 1981) and maximum-parsimony (Fitch, 1971) methods. A phylogenetic tree and distance matrix were reconstructed using the neighbour-joining method of Saitou \& Nei (1987) from $K_{\text {nuc }}$ values (Kimura, 1980, 1983) using MEGA version 4.0 (Tamura et al., 2007). Topology of the phylogenetic tree was evaluated by the bootstrap resampling method of Felsenstein (1985) with 1000 replicates. 
Chromosomal DNA for determination of the G+C content was prepared by following the method of Marmur (1961). The G+C content of the genomic DNA was determined by the HPLC method according to Mesbah et al. (1989). DNA-DNA hybridization was performed fluorometrically by the methods of Ezaki et al. (1989) and He et al. (2005) using photobiotin-labelled DNA probes and microdilution wells. Hybridization was performed with five replications for each sample and the highest and lowest values in each sample were excluded. The DNADNA relatedness values are expressed as the means of the remaining three values.

Strain YIM M $10931^{\mathrm{T}}$ produced abundantly branched, nonfragmenting substrate mycelium and aerial hyphae, which differentiated into spore chains. Short spore chains were hooked or spiral (1-3 turns) and were composed of 4 to 6 spores, whose surfaces were smooth (Fig. S1, available in IJSEM Online). The aerial mycelium was abundant and white to pale yellow-pink in colour on most media tested. The substrate mycelium was white to grey-brown and produced a deep brown pigment on some media (Table S1, available in IJSEM Online). Strain YIM M $10931^{\mathrm{T}}$ grew well at $\mathrm{pH} 7-8$ and in up to $7 \%(\mathrm{w} / \mathrm{v}) \mathrm{NaCl}$. The optimum growth temperature was $37^{\circ} \mathrm{C}$. Strain YIM M $10931^{\mathrm{T}}$ and two reference type strains (A. cremea DSM $43676^{\mathrm{T}}$ and $A$. rifamycini DSM $43936^{\mathrm{T}}$ ) were positive for utilization of mannitol and negative for utilization of dulcitol, glycerol, lactose, D-mannose, maltose, sodium oxalate, sorbitol, trehalose and xylitol as sole carbon sources. The three strains were positive for utilization of L-alanine, L-arginine, L-glutamic acid, glycine, L-histidine, L-lysine, L-phenylalanine, L-proline, L-serine, L-tyrosine and L-valine as sole nitrogen sources. They were positive for catalase activity and nitrate reduction and negative for degradation of cellulose. However, the novel strain differed from these two reference type strains in some phenotypic characteristics (Table 1).

Strain YIM M $10931^{\mathrm{T}}$ exhibited chemical markers that are typical of members of the genus Actinomadura, i.e. it contained: meso-DAP as the cell wall diamino acid; galactose, glucose, madurose, mannose and ribose as whole cell sugars; DPG and PI as major polar lipids (Fig. S2, available in IJSEM Online); MK-9 $\left(\mathrm{H}_{8}\right)$ and $\mathrm{MK}-9\left(\mathrm{H}_{6}\right)$ as the predominant menaquinones; and iso- $\mathrm{C}_{16: 0}, 10$-methyl $\mathrm{C}_{18: 0}$ and $\mathrm{C}_{16: 0}$ as the major fatty acids.

An almost complete $16 \mathrm{~S}$ rRNA gene sequence (1537 nt) was generated for isolate YIM M $10931^{\mathrm{T}}$. Comparative $16 \mathrm{~S}$ rRNA gene sequence analysis showed that strain YIM M $10931^{\mathrm{T}}$ was phylogenetically related to members of the genus Actinomadura (Fig. 1). In the phylogenetic tree based on the neighbour-joining algorithm, strain YIM M $10931^{\mathrm{T}}$ clustered with the type strains of $A$. cremea, A. rifamycini and $A$. apis. This relationship was supported by all treemaking methods used in this study (data not shown). The similarity values of strain YIM M $10931^{\mathrm{T}}$ with A. cremea DSM $43676^{\mathrm{T}}$, A. rifamycini DSM $43936^{\mathrm{T}}$ and A. apis IM17-1 ${ }^{\mathrm{T}}$ were 98.4, 97.4 and $96.9 \%$, respectively. The results of the
16S rRNA gene sequence comparisons further demonstrated that strain YIM M $10931^{\mathrm{T}}$ is a member of the genus Actinomadura.

The genomic DNA G + C content of strain YIM M $10931^{\mathrm{T}}$ was $69.7 \mathrm{~mol} \%$. The levels of DNA-DNA relatedness of strain YIM M $10931^{\mathrm{T}}$ with A. cremea DSM $43676^{\mathrm{T}}$ and $A$. rifamycini DSM $43936^{\mathrm{T}}$ were $49.1 \%$ and $50.8 \%$ (standard deviations were $2.9 \%$ and $3.3 \%$, respectively). These values are well below the $70 \%$ cut-off point recommended for the delineation of genomic species (Wayne et al., 1987).

Strain YIM M $10931^{\mathrm{T}}$ should be placed in the genus Actinomadura based on its morphological characteristics, chemotaxonomic data and relatively high $16 \mathrm{~S}$ rRNA gene sequence similarities with other members of the genus. However, the isolate can be distinguished from its nearest phylogenetic neighbours, A. cremea DSM $43676^{\mathrm{T}}$ and $A$. rifamycini DSM $43936^{\mathrm{T}}$, on the basis of cultural characteristics (data not shown), physiological properties (Table 1) and low DNA-DNA hybridization values. Therefore, the results of the polyphasic taxonomic study presented here allow us to assign the isolate to a novel species, for which we propose the name Actinomadura sediminis sp. nov.

\section{Description of Actinomadura sediminis sp. nov.}

Actinomadura sediminis (se.di'mi.nis. L. gen. n. sediminis of sediment).

Aerobic, Gram-positive. Forms abundantly branched substrate mycelium; aerial hyphae differentiate into hooked or spiral spore chains. Spore surface is smooth. Aerial mycelia are white to pale yellow-pink on most media, but grey-brown on potato-glucose agar; substrate mycelia are white to grey-brown and produce a deep brown diffusible pigment on ISP 2 and nutrient agar. Growth occurs at $28-45{ }^{\circ} \mathrm{C}$ and $\mathrm{pH}$ 7.0-8.0. Tolerates up to $7 \%(\mathrm{w} / \mathrm{v}) \mathrm{NaCl}$. Urea is hydrolysed, but cellulose, gelatin, starch, and Tweens 20, 40 and 80 are not. Negative for milk coagulation and peptonization. Positive for catalase, oxidase, $\mathrm{H}_{2} \mathrm{~S}$ production and nitrate reduction. Utilizes L-arabinose, D-fructose, D-galactose, mannitol, Lrhamnose, ribose and D-xylose as sole carbon sources. Dulcitol, cellobiose, glucose, inositol, lactose, mannose, maltose, raffinose, sodium citrate, sodium oxalate, sorbitol, sucrose, trehalose and xylitol are not utilized. L-Alanine, Larginine, L-asparagine, L-glutamic acid, glycine, L-histidine, L-hydroxyproline, hypoxanthine, L-lysine, L-phenylalanine, L-proline, L-serine, L-threonine, L-tyrosine, L-valine and xanthine are used as sole nitrogen sources. The cell wall contains meso-DAP and the whole cell sugars are mannose, ribose, glucose, galactose and madurose. The major phospholipids are DPG, phosphatidylglycerol, PI, phosphatidylinositol mannosides and unknown phospholipids. MK-9 $\left(\mathrm{H}_{8}\right)$ and MK-9 $\left(\mathrm{H}_{6}\right)$ are the major components of the quinone system, with minor amounts of MK-9 $\left(\mathrm{H}_{4}\right)$ and MK-9 $\left(\mathrm{H}_{10}\right)$. The major fatty acids $(>5 \%)$ are $\mathrm{C}_{16: 0}, 10$ methyl $\mathrm{C}_{18: 0}$, iso- $\mathrm{C}_{16: 0}, \mathrm{C}_{18: 1} \omega 9 \mathrm{c}$ and $\mathrm{C}_{18: 0}$. 
Table 1. Differential characteristics of strain YIM M $10931^{\top}$, A. cremea DSM $43676^{\top}$ and A. rifamycini DSM $43936^{\top}$

Strains: 1, A. sediminis sp. nov. YIM M $10931^{\mathrm{T}}$; 2, A. cremea DSM 43676 ${ }^{\mathrm{T}}$; 3, A. rifamycini DSM $43936^{\mathrm{T}}$. Data are from this study except where marked.

\begin{tabular}{|c|c|c|c|}
\hline Characteristic & 1 & 2 & 3 \\
\hline $\mathrm{pH}$ range & $7-8$ & $6-8$ & $5-7$ \\
\hline Temperature range $\left({ }^{\circ} \mathrm{C}\right)$ & $28-45$ & $28-37$ & $28-45$ \\
\hline Milk coagulation & - & + & - \\
\hline Milk peptonization & - & + & - \\
\hline $\mathrm{H}_{2} \mathrm{~S}$ production & + & - & - \\
\hline \multicolumn{4}{|l|}{ Degradation of: } \\
\hline Gelatin & - & + & - \\
\hline Starch & - & + & - \\
\hline Urea & + & + & - \\
\hline Tween 20 & - & + & + \\
\hline Tween 40 & - & + & + \\
\hline Tween 80 & - & + & + \\
\hline \multicolumn{4}{|l|}{ Sensitivity to antibiotics: } \\
\hline Erythromycin & - & + & - \\
\hline Norfloxacin & - & - & + \\
\hline Gentamicin & - & - & + \\
\hline Ampicillin & + & - & + \\
\hline Vancomycin & - & - & + \\
\hline Chloramphenicol & - & + & - \\
\hline Novobiocin & - & - & + \\
\hline Rifampicin & - & + & - \\
\hline \multicolumn{4}{|l|}{ Utilization as sole carbon source: } \\
\hline L-Arabinose & + & + & - \\
\hline Cellobiose & - & + & - \\
\hline D-Fructose & + & + & - \\
\hline D-Galactose & + & - & - \\
\hline Glucose & - & + & - \\
\hline Inositol & - & + & - \\
\hline Raffinose & - & + & - \\
\hline L-Rhamnose & + & + & - \\
\hline D-Ribose & + & + & - \\
\hline Sucrose & - & + & - \\
\hline Sodium citrate & - & - & + \\
\hline D-Xylose & + & + & - \\
\hline \multicolumn{4}{|c|}{ Utilization as sole nitrogen source: } \\
\hline L-Hydroxyproline & + & - & + \\
\hline Xanthine & + & - & + \\
\hline L-Threonine & + & - & + \\
\hline Major (>5\%) fatty acids (\%) & $\begin{array}{c}\mathrm{C}_{16: 0}(28.05), 10 \text {-methyl } \mathrm{C}_{18: 0} \\
(20.75), \text { iso- } \mathrm{C}_{16: 0}(16.18), \\
\mathrm{C}_{18: 1} \omega 9 c(9.03), \mathrm{C}_{18: 0}(8.20)\end{array}$ & $\begin{array}{c}\mathrm{C}_{16: 0}(41.2), \mathrm{C}_{18: 1} \omega 9 c(14.6) \\
10 \text {-methyl } \mathrm{C}_{18: 0}(13.4)\end{array}$ & $\begin{array}{c}\mathrm{C}_{16: 0}(40.9), \mathrm{C}_{18: 1} \omega 9 c \\
\text { (25.6), 10-methyl } \\
\mathrm{C}_{18: 0}(9.4)\end{array}$ \\
\hline Menaquinones (\%) & 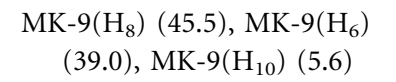 & $\begin{array}{l}\text { MK-9 }\left(\mathrm{H}_{8}\right)(6), \text { MK- } 9\left(\mathrm{H}_{6}\right) \\
\quad(83), \text { MK- } 9\left(\mathrm{H}_{4}\right)(11)^{*}\end{array}$ & $\begin{array}{l}\text { MK-9 }\left(\mathrm{H}_{8}\right)(48.1) \\
\left.\text { MK-9( } \mathrm{H}_{6}\right)(44.4)\end{array}$ \\
\hline Whole cell sugars $\dagger$ & Man, Rib, Glc, Gal, Mad & Man, Rib, Glc, Mad ${ }^{*}$ & $\begin{array}{l}\text { Man, Rib, Glc, Gal, } \\
\text { Mad, Ara }{ }^{*}\end{array}$ \\
\hline DNA G $+C$ content $(\mathrm{mol} \%)$ & 69.7 & $71.1^{*}$ & $73.4^{*}$ \\
\hline
\end{tabular}

${ }^{\star}$ Data from Kroppenstedt et al. (1990).

$\dagger$ Man, Mannose; Rib, ribose; Glc, glucose; Gal, galactose; Mad, madurose; Ara, arabinose. 


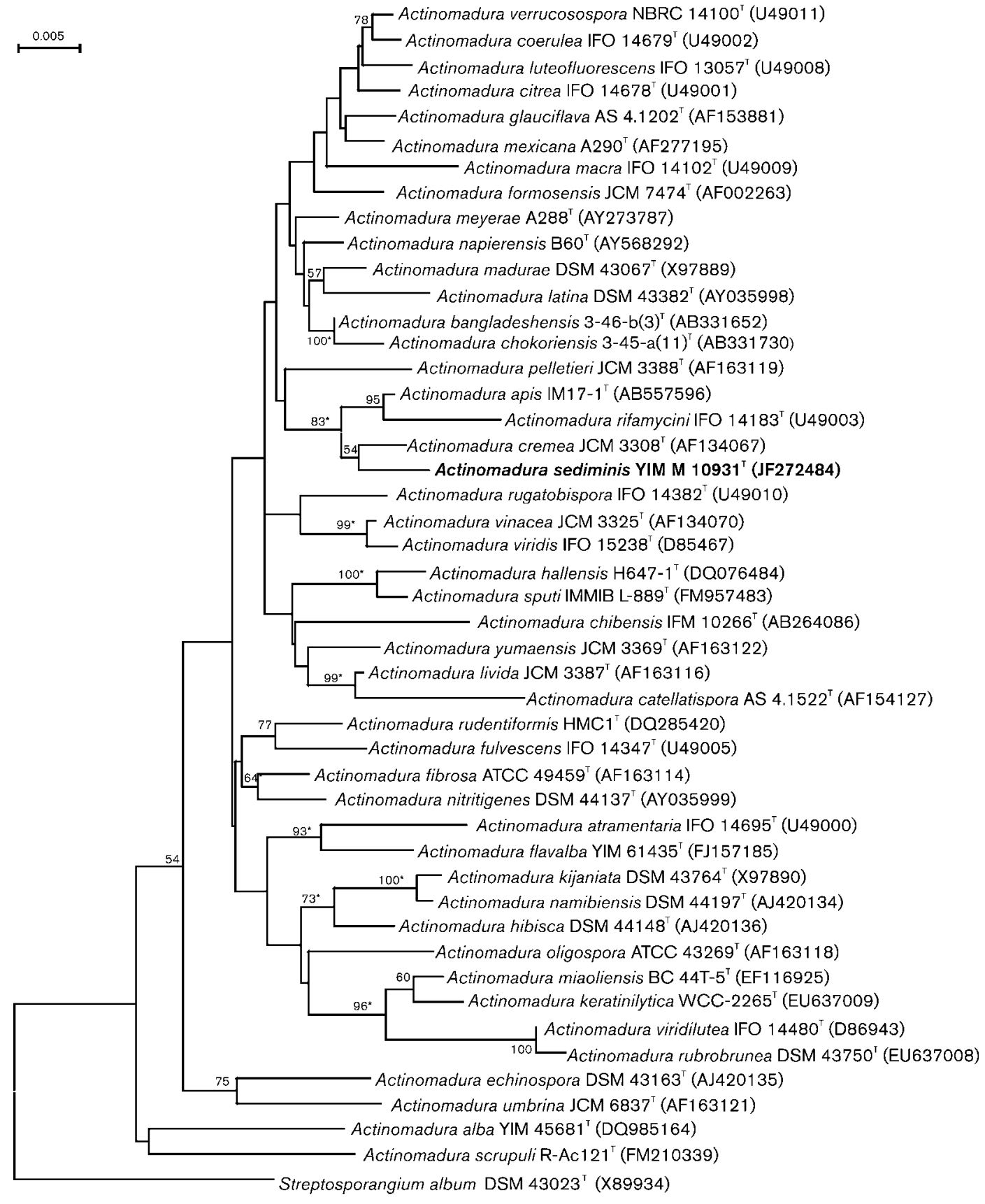

Fig. 1. Neighbour-joining tree (Saitou \& Nei, 1987) based on nearly complete $16 \mathrm{~S}$ rRNA gene sequences (1500 bp length) showing relationships between strain YIM M $10931^{\top}$ and other members of the genus Actinomadura. Asterisks indicate branches of the tree that were also found using the maximum-likelihood (Felsenstein, 1981) and maximum-parsimony (Fitch, 1971 ) tree-making algorithms. Numbers on branch nodes are bootstrap values (1000 resamplings; only values over $50 \%$ are given). The sequence of Streptosporangium album DSM $43023^{\top}$ was used as the outgroup. Bar, 0.005 substitutions per nucleotide position.

The type strain, YIM M $10931^{\mathrm{T}}\left(=\right.$ CCTCC AA $2010009^{\mathrm{T}}$ $=$ DSM $45500^{\mathrm{T}}$ ), was isolated from a mangrove sediment collected from Dugong Creek, Little Andaman, India. The genomic DNA $\mathrm{G}+\mathrm{C}$ content of the type strain is $69.7 \mathrm{~mol} \%$.

\section{Acknowledgements}

We are very grateful to Professor Hans-Peter Klenk (DSMZ) for his kind provision of the reference type strains of A. cremea DSM $43676^{\mathrm{T}}$ and $A$. rifamycini DSM $43936^{\mathrm{T}}$. This research was supported by the National Basic Research Program of China (no. 2010CB833801). 
W.-J.L. was also supported by the 'Hundred Talents Program' of the Chinese Academy of Sciences.

\section{References}

Alongi, D. M. (1988). Bacterial productivity and microbial biomass in tropical mangrove sediments. Microb Ecol 15, 59-79.

Athalye, M., Goodfellow, M., Lacey, J. \& White, R. P. (1985). Numerical classification of Actinomadura and Nocardiopsis. Int $J$ Syst Bacteriol 35, 86-98.

Bauer, A. W., Kirby, W. M. M., Sherris, J. C. \& Turck, M. (1966). Antibiotic susceptibility testing by a standardized single disk method. Am J Clin Pathol 45, 493-496.

Collins, M. D. \& Jones, D. (1980). Lipids in the classification and identification of coryneform bacteria containing peptidoglycans based on 2,4-diaminobutyric acid. J Appl Bacteriol 48, 459-470.

Collins, M. D., Pirouz, T., Goodfellow, M. \& Minnikin, D. E. (1977). Distribution of menaquinones in actinomycetes and corynebacteria. J Gen Microbiol 100, 221-230.

Ezaki, T., Hashimoto, Y. \& Yabuuchi, E. (1989). Fluorometric deoxyribonucleic acid-deoxyribonucleic acid hybridization in microdilution wells as an alternative to membrane filter hybridization in which radioisotopes are used to determine genetic relatedness among bacterial strains. Int J Syst Bacteriol 39, 224-229.

Felsenstein, J. (1981). Evolutionary trees from DNA sequences: a maximum likelihood approach. J Mol Evol 17, 368-376.

Felsenstein, J. (1985). Confidence limits on phylogenies: an approach using the bootstrap. Evolution 39, 783-791.

Fitch, W. M. (1971). Toward defining the course of evolution: minimum change for a specific tree topology. Syst Zool 20, 406-416.

Goodfellow, M. (1971). Numerical taxonomy of some nocardioform bacteria. J Gen Microbiol 69, 33-80.

He, L., Li, W., Huang, Y., Wang, L. M., Liu, Z. H., Lanoot, B. J., Vancanneyt, M. \& Swings, J. (2005). Streptomyces jietaisiensis sp. nov., isolated from soil in northern China. Int J Syst Evol Microbiol 55, 1939-1944.

Holguin, G., Vazquez, P. \& Bashan, Y. (2001). The role of sediment microorganisms in the productivity, conservation, and rehabilitation of mangrove ecosystems: an overview. Biol Fertil Soils 33, 265-278.

Holguin, G., Gonzalez-Zamorano, P., de-Bashan, L. E., Mendoza, R., Amador, E. \& Bashan, Y. (2006). Mangrove health in an arid environment encroached by urban development - a case study. Sci Total Environ 363, 260-274.

Kathiresan, K. \& Bingham, B. L. (2001). Biology of mangroves and mangrove ecosystems. Adv Mar Biol 40, 81-251.

Kawato, N. \& Shinobu, R. (1959). On Streptomyces herbaricolor sp. nov. Supplement: a simple technique for the microscopic observation. Mem Osaka Univ Lib Arts Educ B Nat Sci 8, 114-119.

Kelly, K. L. (1964). Inter-Society Color Council - National Bureau of Standards Color-Name Charts Illustrated with Centroid Colors. Washington, DC: US Government Printing Office.

Kimura, M. (1980). A simple method for estimating evolutionary rates of base substitutions through comparative studies of nucleotide sequences. J Mol Evol 16, 111-120.

Kimura, M. (1983). The Neutral Theory of Molecular Evolution. Cambridge: Cambridge University Press.

Kroppenstedt, R. M., Stackebrandt, E. \& Goodfellow, M. (1990). Taxonomic revision of the actinomycete genera Actinomadura and Microtetraspora. Syst Appl Microbiol 13, 148-160.
Lechevalier, H. A. \& Lechevalier, M. P. (1968). A critical evaluation of the genera of aerobic actinomycetes. In The Actinomycetales, pp. 393405. Edited by H. Prauser. Jena: VEB Gustav Fischer Verlag.

Lee, D. W. \& Lee, S. D. (2010). Actinomadura scrupuli sp. nov., isolated from rock. Int J Syst Evol Microbiol 60, 2647-2651.

Li, W. J., Xu, P., Schumann, P., Zhang, Y. Q., Pukall, R., Xu, L. H., Stackebrandt, E. \& Jiang, C. L. (2007). Georgenia ruanii sp. nov., a novel actinobacterium isolated from forest soil in Yunnan (China), and emended description of the genus Georgenia. Int J Syst Evol Microbiol 57, 1424-1428.

Marmur, J. (1961). A procedure for the isolation of deoxyribonucleic acid from microorganisms. J Mol Biol 3, 208-218.

Mesbah, M., Premachandran, U. \& Whitman, W. B. (1989). Precise measurement of the $\mathrm{G}+\mathrm{C}$ content of deoxyribonucleic acid by high performance liquid chromatography. Int J Syst Bacteriol 39, 159-167.

Minnikin, D. E., Collins, M. D. \& Goodfellow, M. (1979). Fatty acid and polar lipid composition in the classification of Cellulomonas, Oerskovia and related taxa. J Appl Bacteriol 47, 87-95.

Pridham, T. G. \& Gottlieb, G. (1948). The utilization of carbon compounds by some Actinomycetales as an aid for species determination. J Bacteriol 56, 107-114.

Promnuan, Y., Kudo, T., Ohkuma, M. \& Chantawannakul, P. (2011). Actinomadura apis sp. nov., isolated from a honey bee (Apis mellifera) hive, and the reclassification of Actinomadura cremea subsp. rifamycini Gauze et al. 1987 as Actinomadura rifamycini (Gauze et al. 1987) sp. nov., comb. nov. Int J Syst Evol Microbiol 61, 2271-2277.

Saitou, N. \& Nei, M. (1987). The neighbor-joining method: a new method for reconstructing phylogenetic trees. Mol Biol Evol 4, 406-425.

Sasser, M. (1990). Identification of bacteria by gas chromatography of cellular fatty acids. USFCC Newsl 20, 16.

Shirling, E. B. \& Gottlieb, D. (1966). Methods for characterization of Streptomyces species. Int J Syst Bacteriol 16, 313-340.

Staneck, J. L. \& Roberts, G. D. (1974). Simplified approach to identification of aerobic actinomycetes by thin-layer chromatography. Appl Microbiol 28, 226-231.

Tamaoka, J., Katayama-Fujimura, Y. \& Kuraishi, H. (1983). Analysis of bacterial menaquinone mixtures by high performance liquid chromatography. J Appl Bacteriol 54, 31-36.

Tamura, K., Dudley, J., Nei, M. \& Kumar, S. (2007). MEGA4: Molecular Evolutionary Genetics Analysis (MEGA) software version 4.0. Mol Biol Evol 24, 1596-1599.

Tamura, T., Ishida, Y., Nozawa, Y., Otoguro, M. \& Suzuki, K.-I. (2009). Transfer of Actinomadura spadix Nonomura and Ohara 1971 to Actinoallomurus spadix gen. nov., comb. nov., and description of Actinoallomurus amamiensis sp. nov., Actinoallomurus caesius sp. nov., Actinoallomurus coprocola sp. nov., Actinoallomurus fulvus sp. nov., Actinoallomurus iriomotensis sp. nov., Actinoallomurus luridus sp. nov., Actinoallomurus purpureus sp. nov. and Actinoallomurus yoronensis sp. nov. Int J Syst Evol Microbiol 59, 1867-1874.

Tang, S.-K., Wang, Y., Chen, Y., Lou, K., Cao, L.-L., Xu, L.-H. \& Li, W.-J. (2009). Zhihengliuella alba sp. nov., and emended description of the genus Zhihengliuella. Int J Syst Evol Microbiol 59, 2025-2033.

Thompson, J. D., Gibson, T. J., Plewniak, F., Jeanmougin, F. \& Higgins, D. G. (1997). The CLUSTAL_X windows interface: flexible strategies for multiple sequence alignment aided by quality analysis tools. Nucleic Acids Res 25, 4876-4882.

Trujillo, M. E. \& Goodfellow, M. (2003). Numerical phenetic classification of clinically significant aerobic sporoactinomycetes and related organisms. Antonie van Leeuwenhoek 84, 39-68. 
Wayne, L. G., Brenner, D. J., Colwell, R. R., Grimont, P. A. D., Kandler, O., Krichevsky, M. I., Moore, L. H., Moore, W. E. C., Murray, R. G. E. \& other authors (1987). Report of the ad hoc committee on reconciliation of approaches to bacterial systematics. Int J Syst Bacteriol 37, 463464.
Xu, J., Wang, Y., Xie, S.-J., Xu, J., Xiao, J. \& Ruan, J.-S. (2009). Streptomyces xiamenensis sp. nov., isolated from mangrove sediment. Int J Syst Evol Microbiol 59, 472-476.

Zhang, Z., Wang, Y. \& Ruan, J. (1998). Reclassification of Thermomonospora and Microtetraspora. Int J Syst Bacteriol 48, 411-422. 